\title{
PIRAMIDA: PENINGGALAN KARYA SENI DUNIA DARI WILAYAH BARAT HINGGA TIMUR (BAGIAN I)
}

\author{
Hanny Wijaya \\ Jurusan Desain Komunikasi Visual, Fakultas Komunikasi dan Multimedia, BINUS University \\ Jln. K.H. Syahdan No. 9, Kemanggisan, Palmerah, Jakarta Barat 11480 \\ hwijaya@binus.edu
}

\begin{abstract}
There is a terminology that human learn from the past to reach a better future. Based on this understanding, human start to learn history. Scientists learn history from historical building and cultural heritage from the past. One of the most important buildings is pyramid. For quite a long time, many people do not know that pyramid is only a fundamental form. Everytime people hear a word 'pyramid', they will directly refer to Egyptian Pyramid. However, there are many different forms of pyramid and they were scattered around the world, from western to eastern countries. Besides Egypt, some countries that have been well-known about their pyramids are Mesopotamia, Egypt, Sudan, Nigeria, Greece, Spain, China, Mexico, North America, Italy, India and Indonesia. In this first part of research, it will discuss Egyptian and Mesopotamian Pyramids as the oldest western cultural heritage in the world. Hopefully, this research will enhance the knowledge about pyramids more specific and reader will be able to differentiate the function and form of each pyramid in the world.
\end{abstract}

Keywords: pyramid, history, mythology, spiritual, western

\begin{abstract}
ABSTRAK
Ada sebuah istilah yang menyatakan bahwa manusia belajar dari masa lalu untuk mencapai masa depan yang lebih baik. Berdasarkan pada pemahaman itulah maka manusia mempelajari sejarah. Para ilmuwan mempelajari sejarah dari berbagai bangunan dan benda peninggalan dari kebudayaan di masa lalu. Salah satu bangunan bersejarah adalah bangunan piramida. Selama ini banyak yang kurang mengetahui bahwa sesungguhnya bangunan piramida hanya merupakan bentuk dasar semata, karena ketika mereka mendengar kata 'piramida', maka yang diketahui secara umum adalah piramida Mesir. Padahal sesungguhnya piramida banyak bentuk lainnya dan tersebar hampir di seluruh penjuru dunia. Beberapa negara yang tercatat memiliki peninggalan bersejarah berupa piramida selain Mesir antara lain adalah Mesopotamia, Mesir, Sudan, Nigeria, Yunani, Spanyol, Cina, Meksiko, Amerika Utara, Italia, India dan Indonesia. Pada pembahasan bagian pertama ini, kita akan membahas mengenai piramida Mesir dan Mesopotamia merupakan peninggalan tertua dari kebudayaan barat di dunia. Penelitian ini diharapkan dapat menambah pengetahuan mengenai piramida lebih spesifik dan pembaca mampu untuk membedakan fungsi dan bentuk dari masing-masing piramida dari berbagai bangsa di dunia.
\end{abstract}

Kata kunci: piramida, sejarah, mitologi, spiritual, barat 


\section{PENDAHULUAN}

Pertama kali mendengar kata piramida, yang terbentuk dalam bayangan dan imaji visual kita adalah sebuah bangunan yang berbentuk limas dan terbuat dari batu besar yang kokoh. Kemudian kata yang selanjutnya muncul adalah Mesir, karena dalam lingkup pengetahuan kita, piramida selalu diasosiasikan dengan negara Mesir, yang memang merupakan negara asal munculnya bangunan piramida yang merupakan bangunan peninggalan bersejarah. Apakah memang piramida hanya ada di Mesir? Berdasarkan pertanyaan itulah maka muncul topik penelitian untuk mempelajari mengenai masalah ini lebih lanjut. Ternyata berdasarkan penelitian yang telah dilakukan sejak berabad-abad yang lalu, banyak peninggalan-peninggalan bersejarah dari berbagai negara yang sering disetarakan atau disamakan dengan bangunan piramida. Walaupun bentuk fisik dan fungsional dari bangunan piramida di setiap negara tersebut berbeda-beda.

Beberapa negara yang tercatat memiliki peninggalan bersejarah berupa bangunan berbentuk piramida antara lain adalah Mesopotamia, Mesir, Sudan, Nigeria, Yunani, Spanyol, Cina, Meksiko, Amerika Utara, Italia, India dan Indonesia. Namun sebagai pusat kebudayaan tertua di dunia, Mesopotamia dan Mesir tetap menjadi pusat peninggalan bangunan piramida yang utama, walau mempunyai fungsi yang sangat berbeda. Selain bentuk dan fungsi, piramida dari berbagai negara tersebut juga memiliki nilai filosofis, spiritual dan mengandung muatan budaya dari setiap wilayah dan masyarakatnya masing-masing. Oleh karena itu, penting sekali untuk mempelajari dan melakukan penelitian lebih spesifik mengenai perbedaan dan perkembangan kebudayaan masyarakat dilihat dari bangunan peninggalannya yang telah bertahan selama ratusan bahkan ribuan tahun.

Tujuan dari penelitian mengenai bangunan piramida adalah untuk mengetahui dan mempelajari lebih dalam mengenai budaya dan kehidupan masyarakat di masing-masing wilayah dari segi historis dan antropologisnya. Dengan mengetahui latar belakang dan perkembangan budaya masyarakat tersebut, maka hal tersebut tentunya akan memberi gambaran yang jelas untuk memahami persamaan, perbedaan, dan perkembangan di masing-masing wilayah. Pengetahuan ini diharapkan dapat membuka wawasan kita, dan bisa diambil keunggulannya untuk diterapkan di wilayah kita masing-masing demi menjaga kelestarian peninggalan seni budaya.

\section{METODE}

Penulisan disusun menggunakan pendekatan studi literatur dan studi data dari jaringan elektronik yang dijadikan sumber informasi utama dari penelitian ini. Kemudian penulis mengembangkan data-data dan informasi yang ada dari sumber informasi tersebut dengan menambahkan informasi lanjut yang berdasarkan pada pengamatan, hipotesa dan pengembangan ide dari materi yang ada.

\section{PEMBAHASAN}

Berdasarkan kamus besar Bahasa Indonesia, piramida didefinisikan sebagai bangunan dari batu berbentuk limas (Poerwadarminta, 2006). Sesuai dengan definisinya, bangunan piramida merupakan bangunan yang unik dengan bentuk limas atau bentuk yang merunjung ke atas. Bangunan ini memiliki konstruksi yang kuat dan biasanya dibangun dengan menggunakan material batu yang sangat kuat, sehingga bangunan ini mampu bertahan sangat lama. Setelah ini kita akan membahas perkembangan kebudayaan masyarakat dari beberapa negara yang memiliki bangunan piramida sebagai peninggalan bersejarah mereka. 


\section{Piramida Mesir}

Seperti yang sempat disinggung sebelumnya pada bab pendahuluan, apabila kita mendengar kata piramida, maka kata selanjutnya yang teringat secara otomatis adalah Mesir. Hal ini berdasar pada sejarah dunia yang menjelaskan bahwa peninggalan bangunan piramida yang paling terkenal di dunia adalah bangunan piramida di negara Mesir. Sebagai salah satu negara dengan peradaban dan kebudayaan tertua, Mesir merupakan asal-muasal munculnya berbagai bidang ilmu pengetahuan. Kebudayaan Mesir dijadikan sebagai acuan bagi kebudayaan bangsa-bangsa lain untuk menemukan dan mengembangkan identitas diri bangsa mereka.

Berdasarkan sejarahnya, dahulu orang Mesir kuno menyebut negaranya dengan Kemet, yang memiliki arti black land atau tanah hitam yang berarti tanah yang subur. Mereka menyebut gurun dengan Deshret, yang berarti red land atau tanah merah yang berarti tanah yang gersang. Walaupun masyarakat Mesir hidup di wilayah yang cukup subur, karena pada umumnya mereka hidup di wilayah sekitar sungai Nil, namun keadaan geografis di wilayah Mesir yang tidak stabil karena sering terjadi badai pasir, angin besar dan dingin di malam hari dan matahari yang sangat terik di siang hari menyebabkan orang Mesir harus membuat bangunan dengan konstruksi yang kuat dan kokoh untuk menahan terpaan cuaca yang keras.

Bangsa Mesir menganut kepercayaan polytheis, yaitu kepercayaan pada banyak dewa, menyebabkan bangsa ini lebih banyak menciptakan hasil karya seni dan bangunan yang bersifat spiritual. Berdasarkan sudut pandang mitologi, kebudayaan Mesir sangat mengutamakan kehidupan sesudah kematian. Bangsa Mesir mendedikasikan kehidupan mereka di dunia untuk membangun rumah untuk $\mathrm{ka}$ atau soul, bagian dari manusia setelah mereka meninggal. Berdasarkan pada kepercayaan yang tinggi pada kehidupan spiritual mereka, maka bangsa Mesir percaya bahwa manusia memiliki roh. Menurut mereka, apabila manusia tersebut meninggal maka roh tersebut akan menjelma menjadi penghuni kerajaan Osiris, Sang Dewa Kematian, di alam akhirat.

Menurut kepercayaan bangsa Mesir, apabila jasad manusia tetap dipelihara dengan baik di dunia, antara lain seperti dibuatkan patungnya, dilukiskan atau nama sang jenazah tertera pada peti matinya, maka roh tersebut dapat disempurnakan di alam akhirat. Maka muncul tradisi turun-temurun dari leluhur bangsa Mesir untuk mengawetkan jenazah manusia dengan menggunakan proses mumifikasi atau pembalseman. Tata cara perawatan jenazah dan proses pembalseman tersebut diwariskan turun-temurun melalui buku yang disebut dengan Book of The Dead.

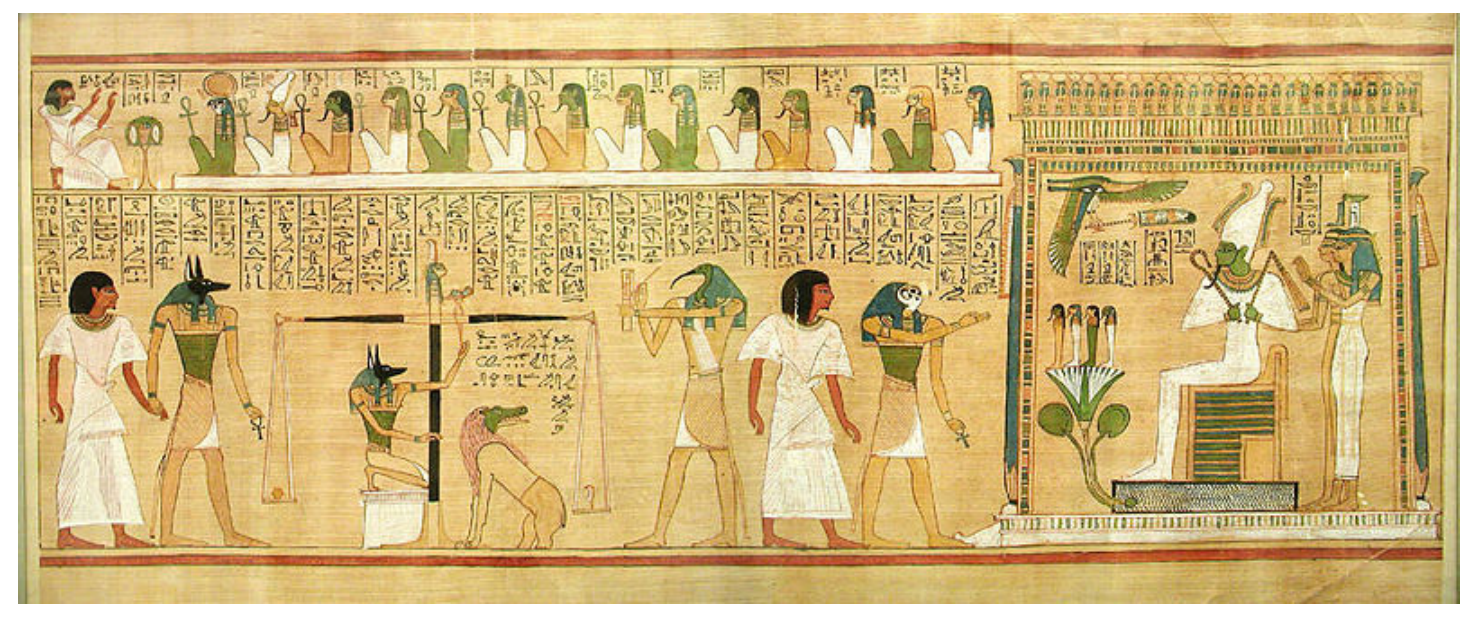

Gambar 1 Book of The Dead 
Pada proses pembalseman, mula-mula jenazah dibedah, kemudian otak, dada dan isi perutnya dikeluarkan. Bagian organ tubuh dalam ini dibubuhi rempah-rempah dan disimpan di dalam sebuah wadah yang berbentuk guci dan disebut dengan geleta. Lalu selanjutnya, tubuh jenazah direndam dengan larutan mineral yang sejenis dengan garam selama beberapa hari supaya mongering dan tidak rusak. Setelah itu, rongga perut dan rongga dada jenazah yang sudah kosong diisi dengan sebangsa damar dan dada dijahit kembali. Langkah terakhir adalah membalut seluruh tubuh jenazah dengan kain putih panjang atau perban, kemudian jenazah tersebut dimasukkan ke dalam sarcophagus atau peti jenazah. Jenazah yang sudah melalui proses pembalseman dan sudah dibungkus di dalam balutan perban tersebut dikenal dengan sebutan mumi (mummy).

Sistem pemerintahan bangsa Mesir adalah kerajaan, penguasa tertingginya adalah raja yang dikenal dengan sebutan Firaun atau Pharaoh. Seperti kerajaan pada umumnya, penerus tahta kerajaan diwariskan turun-temurun. Untuk menjaga keturunan mereka dan silsilah kerajaan tetap berdarah murni, maka pernikahan antar saudara kandung (incest) sudah menjadi hal yang lumrah di dalam kehidupan mereka.

Di era modern, kita telah mengetahui fakta bahwa pernikahan antar saudara kandung sesungguhnya dilarang dan dihindari karena akan mengakibatkan cacat atau kelainan sistem antibodi pada tubuh, namun pada zaman tersebut, fakta mengenai hal ini masih belum diketahui, sehingga banyak pernikahan antar saudara. Mungkin hal inilah yang menyebabkan kematian di usia muda pada masa perkembangan kerajaan Mesir tidak dapat dihindari. Hal ini juga diperkuat oleh hasil penelitian dari para pakar arkeologi yang mempelajari mummy dari pharaoh Tutankhamun, ia merupakan penguasa Mesir pada dinasti ke-18. Para arkeolog mempelajari DNA dari mummy Tutankhamun dan mengetahui bahwa Firaun tersebut juga merupakan anak dari hasil pernikahan saudara kandung (produk incest), karena ayah Tutankhamun, yaitu Firaun Akhenaten dan ibu Tutankhamun diketahui adalah kakak adik. Oleh karena itu Tutankhamun sejak kecil memiliki daya tahan tubuh yang lemah. Firaun Tutankhamun meninggal di usia ke-19 karena ia mengalami komplikasi setelah menderita patah tulang yang parah pada kakinya dan terserang penyakit malaria (Hawass, 2010).

Pentingnya arti kehidupan sesudah kematian bagi roh manusia di dalam kebudayaan Mesir, menyebabkan bangunan makam menjadi sangat penting keberadaannya bagi mereka. Untuk menghormati Firaun sebagai pemimpin tertinggi bagi bangsa Mesir, masyarakatnya kemudian menciptakan bangunan makam yang besar dan megah sebagai tempat persemayaman terakhir jenazah Firaun yang telah meninggal dan melalui proses mumifikasi. Jenazah Firaun pada dinasti awal kebudayaan Mesir disemayamkan di dalam bangunan yang disebut dengan mastaba. Konstruksi dari bangunan mastaba ini terbuat kokoh dari batu mud-brick, dan strukturnya menembus ke dalam tanah. Penggunaan mastaba sebagai bangunan makam hanya bertahan hingga kerajaan Mesir dinasti ke-3 saja, setelah memasuki dinasti ke-4, masyarakat Mesir beralih menggunakan bangunan piramida sebagai bangunan makam.

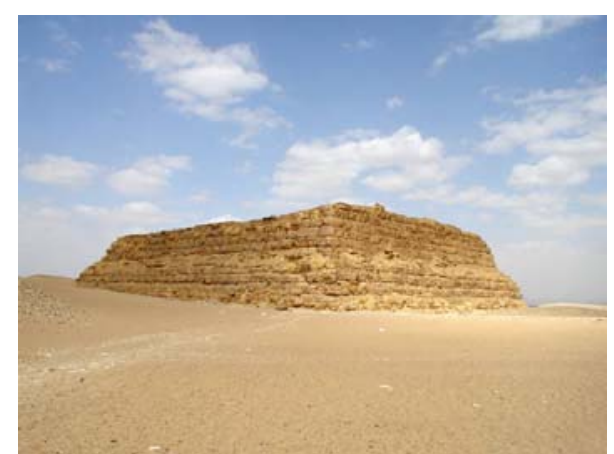

Gambar 2 Bangunan Mastaba

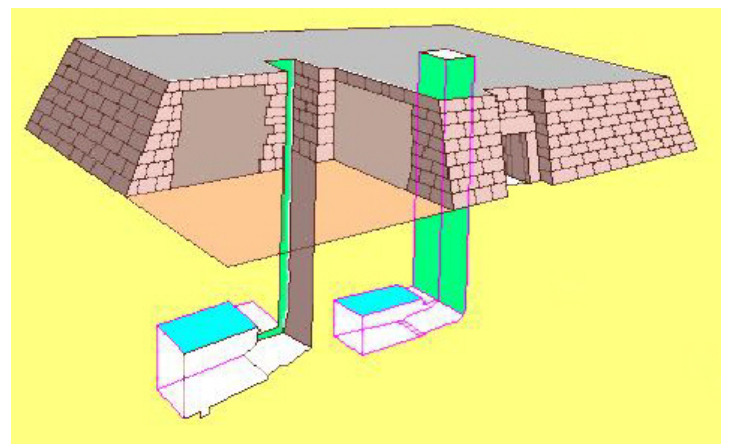

Gambar 3 Pola dan Struktur Bangunan Mastaba 
Setelah masuk ke era dinasti kerajaan ke-4, masyarakat Mesir mulai beralih ke piramida sebagai bangunan makam bagi tempat persemayaman Firaun mereka. Piramida yang paling terkenal di Mesir adalah piramida Khufu atau dikenal dengan sebutan The Great Pyramids of Giza. Piramida ini adalah peninggalan tertua di dunia yang posisinya tidak pernah bergeser dari urutan Tujuh Keajaiban Dunia (Seven Wonders of the World). Piramida Khufu merupakan salah satu piramida yang terdapat di kompleks piramida di Giza dan merupakan piramida yang terbesar bila dibandingkan dengan dua buah bangunan piramida lainnya, yaitu piramida Khafre dan piramida Menkaure. Sesuai dengan namanya, piramida Khufu merupakan makam yang dibuat untuk Pharaoh Khufu yang berkuasa di Mesir pada dinasti ke-4. Selain terbesar, piramida Khufu juga merupakan piramida tertua bila dibandingkan dengan piramida Khafre dan Menkaure.

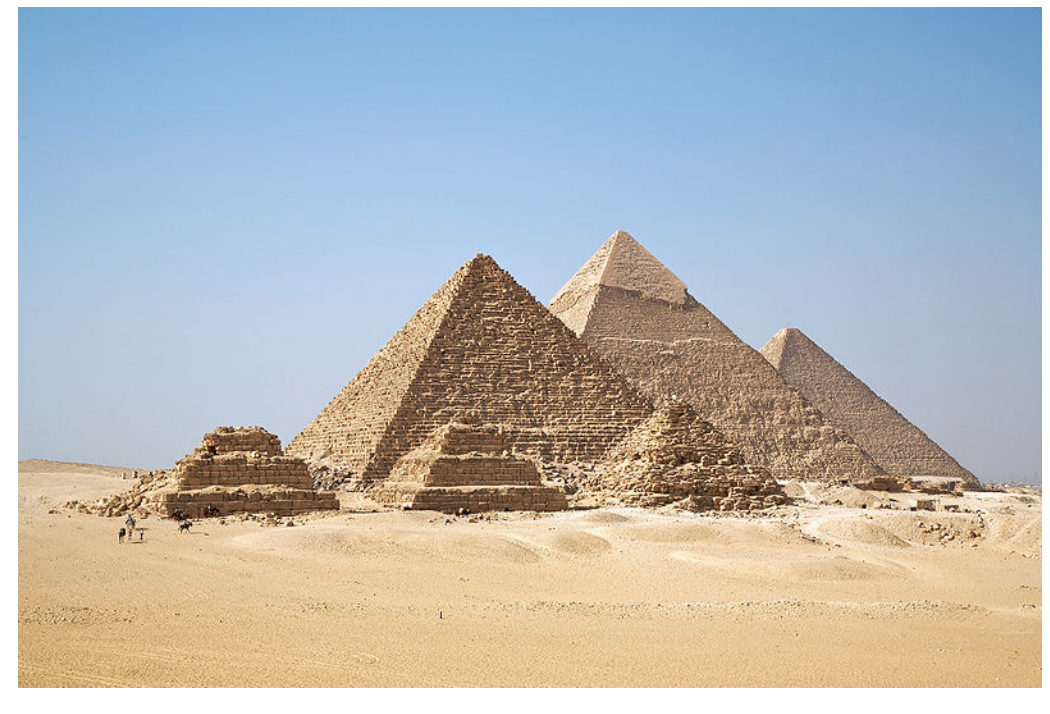

Gambar 4 Kompleks Piramida di Giza, Mesir

Piramida Khafre yang ukurannya relatif sedikit lebih kecil, merupakan piramida kedua terbesar setelah piramida Khufu. Piramida ini merupakan makam Pharaoh Khafre yang merupakan putra dari Pharaoh Khufu. Tradisi dan budaya yang berkembang di Mesir mempercayai bahwa penghormatan terhadap leluhur atau generasi sebelumnya harus dijalankan. Maka keturunan dari Firaun selanjutnya membuat piramida atau makam yang lebih kecil dari orang tua atau leluhurnya, mereka tidak boleh membuat bangunan yang lebih besar karena akan dianggap tidak menghormati leluhur dan tradisi yang berlaku.

Selain piramida Khufu dan Khafre, piramida dengan ukuran terkecil dan dibangun terakhir atau merupakan piramida termuda adalah piramida Menkaure yang merupakan makam dari Pharaoh Menkaure, yang juga merupakan putra dari Pharaoh Khafre. Setelah era Menkaure berakhir, sudah tidak lagi dibangun piramida-piramida besar karena terus terjadi perubahan dan perkembangan dinasti selama ribuan tahun berikutnya. Konstruksi bangunan dari piramida Mesir ini terus bertahan selama ribuan tahun. Material yang digunakan untuk pembangunan piramida ini adalah limestone-block yang dikirim dari wilayah sekitar Mesir. Selain piramida, kekuatan material ini terbukti dari banyaknya peninggalan-peninggalan bangunan bersejarah yang bertahan hingga saat ini karena memanfaatkan material ini, antara lain adalah konstruksi bangunan Roman aqueducts yang ada di Perancis, yaitu bangunan Pont du Gard.

Bentuk piramida yang unik juga didukung oleh struktur dan pembagian pola dan ruang pada bagian dalam bangunan tersebut. Bagi masyarakat Mesir, bangunan piramida bukan hanya sekedar makam untuk tempat menyemayamkan jenazah Firaun, namun juga merupakan rumah bagi roh Firaun itu sendiri. Maka selain dibuatkan proses pembalseman dan diberi peti yang bagus dan indah, 
masyarakat juga memasukkan berbagai harta benda yang sangat berharga, misalnya emas, perhiasan, artefak dan lain sebagainya, untuk dimasukkan bersama dengan peti jenazah ke dalam bangunan makam atau piramida. Maka tidak heran bila sejak dahulu piramida sering dijadikan sasaran untuk perampokan atau pencurian karena banyaknya barang berharga di dalamnya. Hal ini akhirnya mempengaruhi struktur bangunan bagian dalam dari piramida yang sengaja dibuat sangat rumit dan berupa maze yang membingungkan agar tidak mudah dimasuki, atau yang sudah masuk tidak akan bisa keluar untuk membawa pergi barang curiannya. Selain itu, mereka juga memasang kutukankutukan dan jebakan-jebakan untuk mempersulit orang asing masuk ke area bangunan.

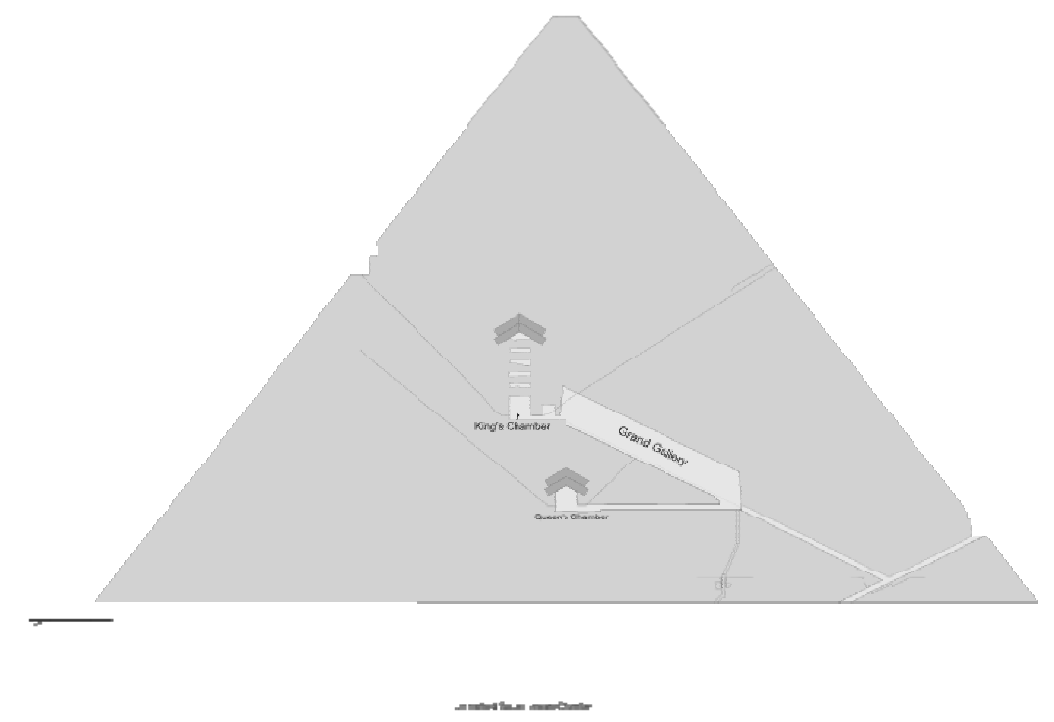

Gambar 5 Struktur Bagian dalam dari Bangunan Piramida Mesir

Selain konstruksi yang kuat dan ukuran yang besar, keunikan kompleks piramida di Giza juga terletak pada tambahan patung raksasa yang dikenal dengan sebutan Sphinx. Sebenarnya sphinx di dalam cerita mitologi memiliki banyak versi. Berdasarkan mitologi Yunani, sphinx merupakan mahluk yang berwujud singa dengan kepala seorang wanita dan bersayap burung elang. Mahluk ini merupakan monster ciptaan Dewi Hera yang ingin menghukum manusia yang ada di kota Thebes. Ciri khas dari mahluk yang disebut dengan Sphinx ini adalah kesukaannya terhadap teka-teki. Ia memberikan pertanyaan berupa teka-teki yang harus dijawab oleh manusia yang ditanya olehnya, bila jawabannya salah maka ia akan memangsa manusia tersebut. Walaupun berdasarkan cerita tersebut, sphinx akhirnya mati bunuh diri dengan melompat ke jurang karena Oedipus berhasil menjawab tekatekinya.

Namun lain halnya dengan sphinx yang merupakan mahluk mitologi Mesir, mahluk ini dibuat dengan wujud singa dengan kepala manusia (laki-laki) dan dipercaya merupakan mahluk penjaga makam, jadi memang tidak sama dengan versi sphinx yang ada di Yunani. Berdasarkan hasil penelitian dari para pakar arkeolog, besar kemungkinan kepala manusia yang ada pada patung Sphinx tersebut adalah kepala dari Pharaoh Khafre yang merupakan keturunan kedua pada dinasti ke-4 kerajaan Mesir. Patung sphinx ini dipercaya merupakan patung penjaga makam piramida Pharaoh Khafre, karena dari sisi peletakan posisi patung sphinx dan piramida Khafre, bila ditarik garis lurus akan menuju arah matahari tenggelam. Maka masyarakat Mesir percaya bahwa roh dari Pharaoh Khafre akan lebih mudah untuk diantarkan ke tempat berkuasanya Dewa Osiris, Sang Penguasa Alam Bawah (Underworld God). 


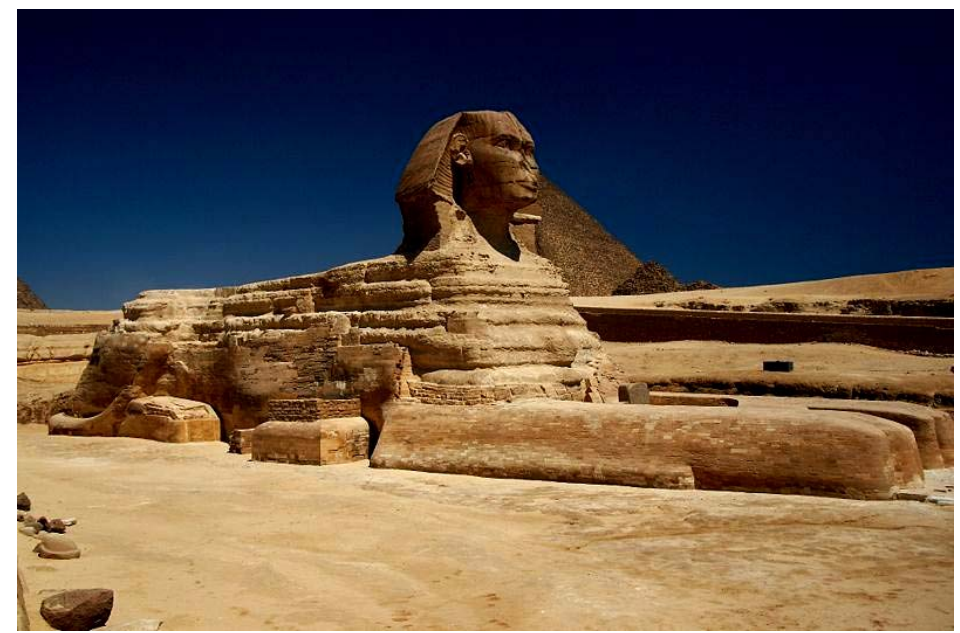

Gambar 6 Sphinx, Mahluk Mitologi Penjaga Makam Mesir

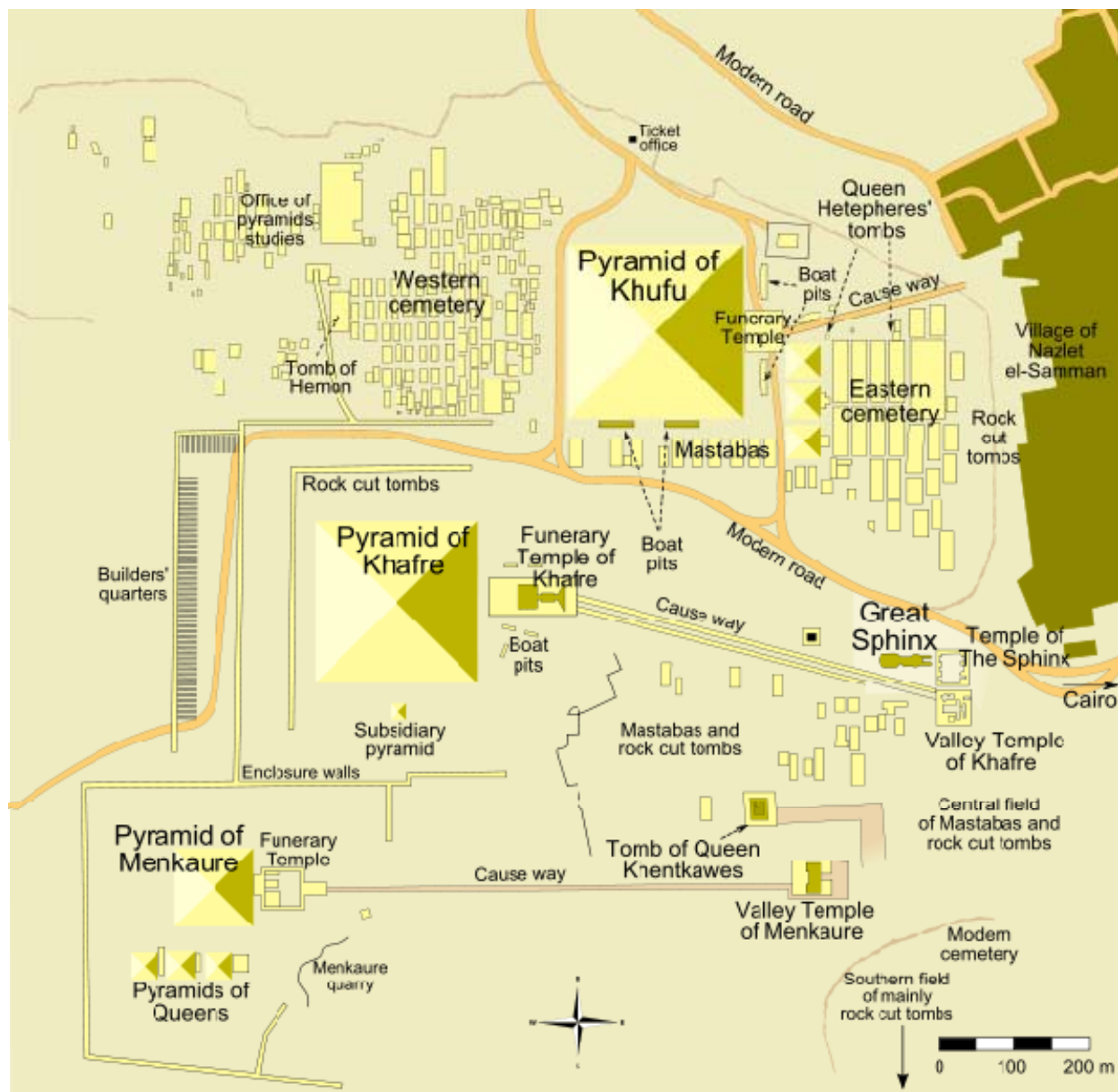

Gambar 7 Kompleks Piramida di Giza, Mesir

Maka dilihat dari segi historis, piramida Mesir menjadi salah satu piramida terbesar, tertua didalam perkembangan kebudayaannya yang masih bertahan sampai saat ini dan menjadi bukti besarnya peradaban manusia sejak dahulu kala. 


\section{Piramida Mesopotamia (Ziggurat)}

Selain piramida yang ada di Mesir, Mesopotamia sebagai salah satu pusat kebudayaan tertua juga memiliki bangunan besar dan kokoh yang berbentuk seperti piramida. Namun dari segi bentuk, bangunan ini tidak total berbentuk seperti bentuk limas, serta mempunyai fungsi yang jauh berbeda dengan piramida Mesir. Berikut akan dibahas perbedaan mendasar dari bangunan tersebut ditinjau dari segi historisnya.

Nama Mesopotamia berasal dari bahasa Yunani, yaitu mesos yang berarti 'tengah' dan potamos yang berarti sungai, maka Mesopotamia memiliki arti wilayah yang ada di antara sungai. Dalam hal ini, wilayah Mesopotamia berada di antara sungai Eufrat dan sungai Tigris. Secara geografis, wilayah ini berupa dataran yang bergunung-gunung. Wilayah Mesopotamia pertama kali dihuni oleh bangsa Sumeria.

Bangsa Sumeria merupakan bangsa pertama yang menemukan sistem penulisan di dunia. Mereka menggunakan cuneiform sebagai sistem penulisan awal untuk mempermudah mereka di dalam kehidupan sehari-hari, seperti sistem perdagangan. Cuneiform merupakan system penulisan dengan menggunakan clay tablet, yaitu bidang pipih dari clay yang setengah kering dan ditulis dengan reed stylus, yaitu batang rumput yang agak keras. Mereka menuliskannya dengan cara menorehkan stylus tersebut di atas tablet yang belum kering tersebut. Sistem penulisan ini berkembang pada periode Uruk, yaitu saat dimulainya system pictographic. Bangsa Sumeria juga memanfaatkan cuneiform untuk menuliskan dan mengabadikan berbagai cerita kepahlawanan dan kisah-kisah lainnya. Salah satu peninggalan mereka yang terkenal adalah kisah Epic of Gilgamesh yang ditulis di atas clay tablet sebanyak 12 buah.

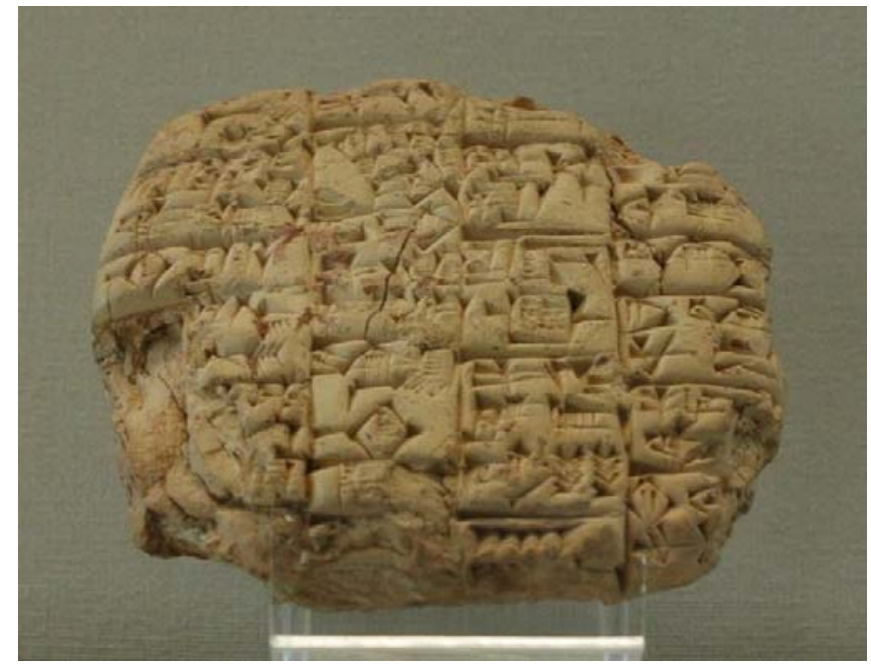

Gambar 8 Contoh Peninggalan Berupa Clay Tablet

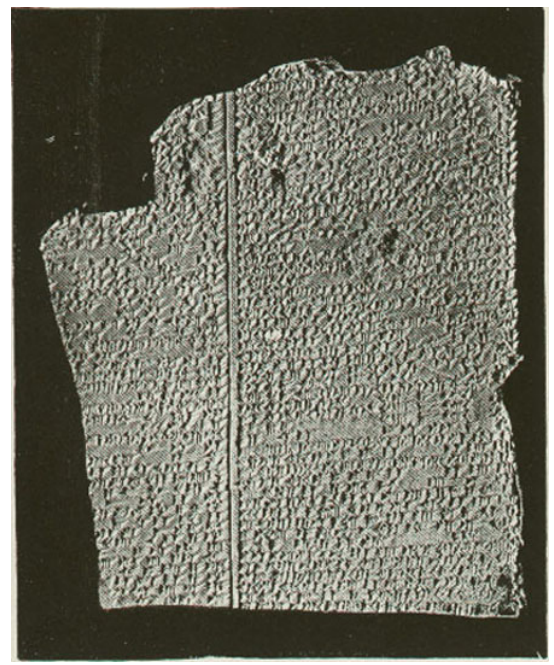

Gambar 9 Tablet Kisah Epic of Gilgamesh

Bangsa Mesopotamia menerapkan polytheis sebagai sistem kepercayaannya, yaitu kepercayaan terhadap banyak dewa. Mereka juga percaya bahwa bumi itu merupakan keping pipih yang dikelilingi oleh lubang hitam besar, kemudian diatasnya adalah surga tempat bernaung dewadewa. Mereka menyebut alam semesta (universe): an-ki, merupakan gabungan dari dewa An (sky), yang merupakan dewa tertinggi, pemimpin pantheon (dewa-dewi lainnya). dan istriNya, dewi Ki (earth). 
Berdasarkan kebutuhan terhadap kegiatan spiritual dari bangsa Mesopotamia, maka dibangunlah kuil untuk pemujaan terhadap dewa-dewa. Mereka membangun sebuah bangunan besar dan kokoh yang bentuknya menyerupai bentuk piramida, yaitu bentuk limas. Namun bentuk dasar bangunannya tidak sama seperti bangunan piramida yang ada di Mesir, dimana bangunan piramida Mesir berbentuk limas secara sempurna. Sedangkan bangunan piramida Mesopotamia berbentuk limas yang terpotong di puncaknya, kemudian pada sisi-sisi bangunannya berundak-undak seperti tangga. Bangunan piramida Mesopotamia ini disebut dengan ziggurat.

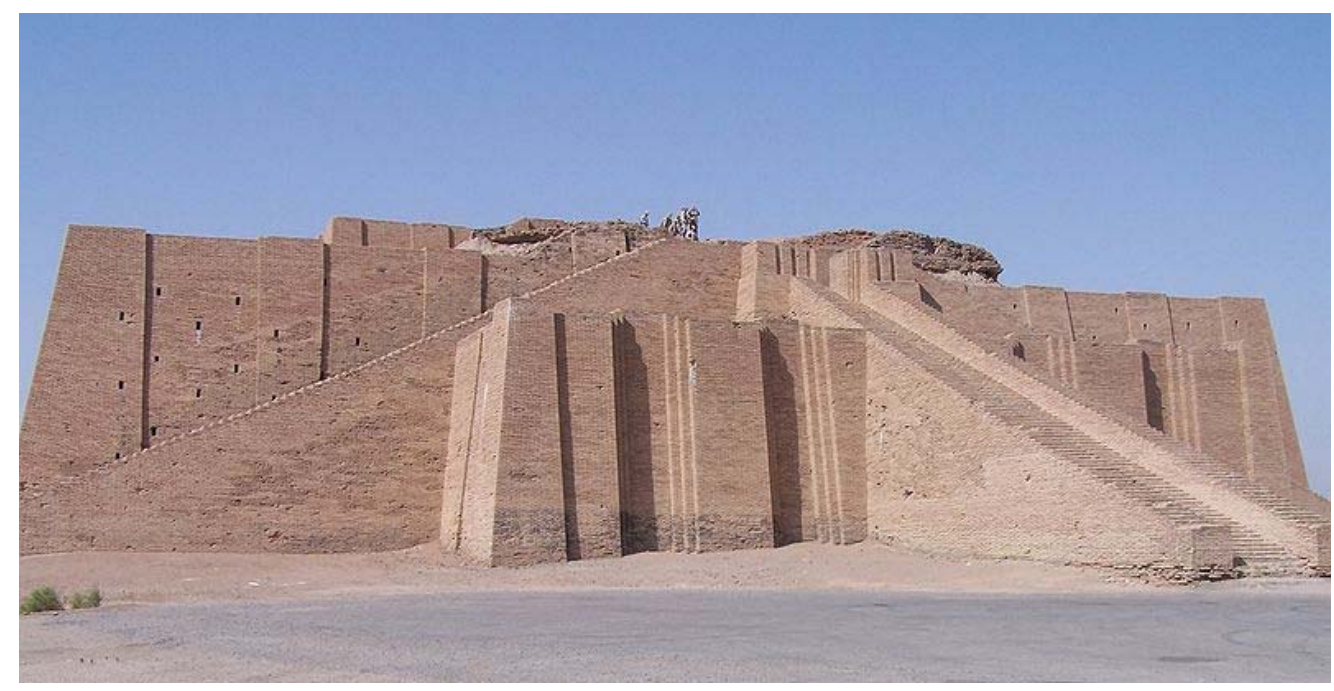

Gambar 10 Neo-Sumerian - Great Ziggurat of Ur

Walaupun bentuknya tidak benar-benar seperti piramida yang berbentuk limas sempurna, namun bentuk limas terpenggal tersebut juga dikategorikan sebagai bangunan piramida bagi banyak historian di berbagai negara. Bentuk piramida terpenggal tersebut juga berlaku pada bentuk piramida yang ada di meksiko (meso-america) dan beberapa wilayah lainnya. Selain bentuk yang berbeda dengan piramida Mesir, bangunan ziggurat juga memiliki fungsi yang sangat berbeda dengan bangunan piramida di Mesir. Apabila bangunan piramida Mesir berfungsi sebagai makam bagi pharaoh atau Firaun mereka, maka bangunan ziggurat memiliki fungsi sebagai kuil tempat pemujaan bagi para dewa-dewa mereka. Maka bangunan piramida bagi bangsa Mesopotamia merupakan bangunan suci tempat menyembah dewa.

Selain bangunan ziggurat, perbandingan lain yang sering dilihat adalah mahluk mitologi penjaga bangunan antara Mesir dan Mesopotamia. Bila Mesir memiliki sphinx sebagai mahluk mitologi penjaga bangunan piramida, maka bangsa Mesopotamia memiliki mahluk yang disebut dengan Lamassu atau Shedu yang merupakan mahluk mitologi penjaga pintu gerbang, umumnya pintu gerbang istana. Memang mahluk ini tidak berkaitan langsung dengan bangunan piramida, namun bentuk dan latar belakang cerita mitologinya yang unik membuat shedu sering dikaitkan dengan sphinx.

Shedu adalah mahluk berbentuk banteng dengan kepala manusia dan bersayap burung elang. Mahluk ini dipercaya merupakan pelindung bangunan, maka biasanya dibuat berupa ukiran berpasangan di pintu gerbang istana atau diukir di atas clay tablet dan dikubur di depan pintu masuk rumah masyarakat Mesopotamia. Tidak seperti sphinx yang dibuat dalam bentuk patung besar, shedu dibuat dalam bentuk ukiran bas-relief atau juga dikenal dengan istilah low-relief, yaitu ukiran dalam yang menghasilkan efek timbul dan dapat diraba. Shedu merupakan salah satu unsur penting di dalam seni bangunan istana atau rumah penduduk Mesopotamia. 


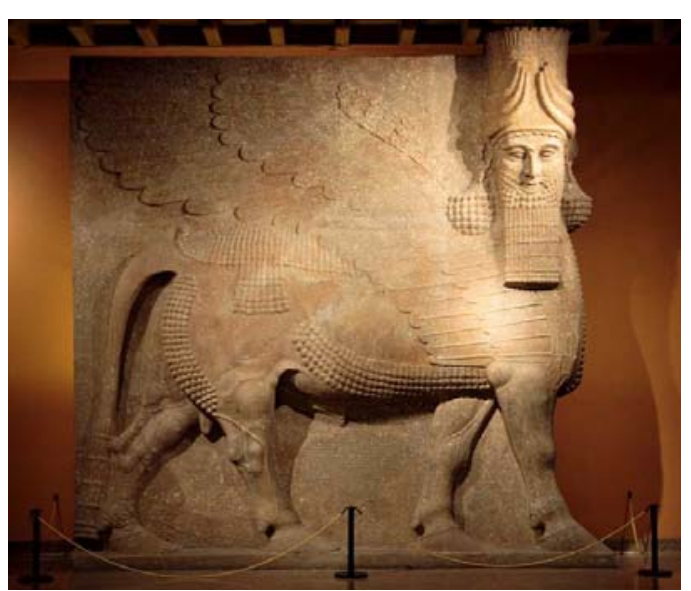

Gambar 11 Shedu atau Lamassu

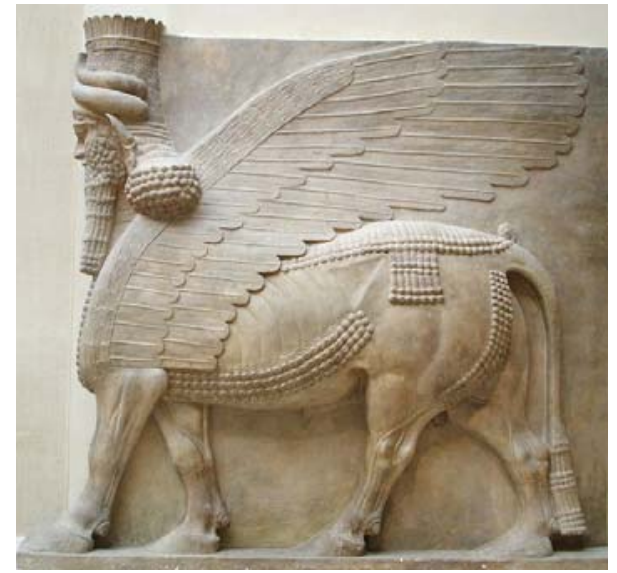

Gambar 12 Shedu di Pintu Gerbang Istana Sargon II

\section{PENUTUP}

Berdasarkan dari dua contoh bangunan piramida dari dua kebudayaan bangsa yang telah dibahas, yaitu Mesir dan Mesopotamia, maka dapat disimpulkan bahwa berdasarkan fakta historis yang ada, setiap bangunan yang dibuat pada masa awal sejarah kebudayaan dunia semuanya erat berkaitan dengan kehidupan masyarakat dari segi spiritual atau unsur kepercayaan. Selain itu, setiap bangunan dan upacara adat kebudayaan masyarakat juga erat kaitannya dengan unsur mitologis yang berkembang di masyarakat pada saat itu. Seperti bangsa Mesir yang membuat bangunan piramida sebagai bangunan makam untuk menghormati pharaoh mereka, dimana mereka percaya bahwa dengan merawat jenazah dengan baik maka perjalanan bagi pharaoh yang mereka cintai dan hormati akan lebih mudah dan lancar untuk diterima di dunia underworld yang dikuasai oleh Dewa Osiris. Begitu pula dengan mahluk mitologi sphinx yang dibuat atas dasar kepercayaan masyarakat Mesir untuk menjaga bangunan makam dengan kekuatan dan kebijaksanaannya. Sedangkan bangsa Mesopotamia membuat bangunan ziggurat sebagai kuil tempat pemujaan bagi dewa-dewa mereka. Mereka juga mengukir mahluk mitologi lamassu atau shedu yang dipercaya akan melindungi rumah kediaman atau tempat tinggal mereka. Sehingga dapat disimpulkan bahwa pada zaman dahulu, mulai dari kebudayaan tertua, bangunan piramida dibuat umumnya untuk memenuhi kebutuhan spiritual masyarakatnya, yakni dari segi kepercayaan dan untuk mendukung kegiatan keagamaan. Semuanya juga didukung dengan kuatnya dukungan cerita mitologi yang berkembang di masyarakat setiap bangsa. Pada tulisan mengenai piramida bagian awal ini, penulis baru membahas mengenai bangunan peninggalan seni bersejarah, yaitu bangunan piramida dari Mesir dan Mesopotamia saja, namun pembahasan mengenai bangunan piramida dari wilayah lainnya akan dibahas pada bahasan berikutnya, khususnya wilayah timur dan juga wilayah meso-america yang juga tidak kalah penting untuk dibahas dari segi budaya, historis dan mitologis.

\section{DAFTAR PUSTAKA}

Hawass, Z. (2010, September). King Tut's family secrets. National Geographic.

Poerwadarminta, W. J. S. (2006). Kamus umum Bahasa Indonesia. Jakarta: Balai Pustaka. 